\title{
EVALUATION OF CAST IRON DESULFURIZATION WITH SYNTHETIC SLAGS*
}

\author{
Felipe Fardin Grillo ${ }^{1}$ \\ Eduardo Junca ${ }^{2}$ \\ Rodrigo de Oliveira Pezzin ${ }^{3}$ \\ Rüdiger Deike ${ }^{4}$ \\ José Roberto de Oliveira ${ }^{5}$ \\ Gustavo Bretz ${ }^{6}$ \\ Denise Crocce Romano Espinosa ${ }^{7}$
}

\begin{abstract}
The aim of this work was to study the use of slags to desulfurization of cast iron. It was proposed to use alumina instead fluorspar. In addition, marble waste was used instead lime. Simulations applying Thermo-Calc software were performed in order to obtain the theoretical phases thermodynamic data. Then, a comparison between theoretical data and experimental tests were performed. The cast iron was melting in induction furnace at $1550^{\circ} \mathrm{C}$. Slags composed mainly for $\mathrm{CaO}$ and $\mathrm{Al}_{2} \mathrm{O}_{3}$ were used to cast iron desulphurization. It was observed that increasing liquid phase, the desulphurization reaction was favored. Besides, it was found that cast iron desulfurization occurs by top slag mechanism.
\end{abstract}

Keywords: Desulfurization; Fluorspar; Marble waste; Cast iron.

1 Doutor em Engenharia Metalúrgica e de Materiais - USP, Pós-doutorando no Instituto Federal de Educação, Ciência e Tecnologia do Espírito Santo (IFES), Vitória, ES, Brasil.

2 Doutor em Engenharia Metalúrgica e de Materiais - USP, Pós-doutorando no Instituto Federal de Educação, Ciência e Tecnologia do Espírito Santo (IFES), Vitória, ES, Brasil.

3 Engenheiro Metalurgista, Mestrando em Engenharia Metalúrgica e de Materiais no Instituto Federal de Educação, Ciência e Tecnologia do Espírito Santo (IFES), Vitória, ES, Brasil.

4 Prof. Dr.-Ing. Rüdiger Deike, Universität Duisburg-Essen, Institut für Metallurgie und Umformtechnik, Duisburg, Norddrhein-Westfalen, Deutschland.

5 Professor Doutor do programa de pós-graduação em Engenharia Metalúrgica e de Materiais do Instituto Federal de Educação, Ciência e Tecnologia do Espírito Santo (IFES), Vitória, Brasil.

6 Master in Metallurgie und Umformtechnik, Universität Duisburg-Essen, Institut für Metallurgie und Umformtechnik, Duisburg, Nordrhein-Westfalen, Deutschland.

7 Professor Associado do Departamento de Engenharia Química, Universidade de São Paulo (USP), São Paulo, Brasil. 


\section{INTRODUCTION}

According to Roskill, the China produced around $75 \%$ of primary magnesium in the world in 2012. The sum of Russia and USA production was about $16 \%$. Other important countries are Israel, Kazakhstan, Brazil, Serbia and Ukraine ${ }^{(1)}$.

One of the most important process involving cast iron and steel production is desulfurization. Desulfurization of cast iron is practiced in manufacture of ductile iron castings in order to obtain spherical graphite morphology. Ductile iron is used in applications where high fracture toughness is required. Several reagents are employed to remove sulfur, such as: calcium, magnesium and sodium ${ }^{(2)}$. The desulfurization cast iron using magnesium powder wire is related to high operating $\operatorname{cost}^{(3)}$.

The goal of this paper is to substitute metallic magnesium for calcium oxide or marble waste as desulfurization agent.

\section{MATERIALS AND PROCEDURE}

\subsection{Composition of the synthetic slags}

Table 1 shows the composition of the slags used in the experiments

Table 1. Slags compositions used in cast iron desulfurization process.

\begin{tabular}{|c|c|c|c|c|c|c|c|c|c|c|}
\hline \multirow[b]{2}{*}{ Mixtures } & \multicolumn{6}{|c|}{ Composition (wt \%) } & \multicolumn{4}{|c|}{ Mass (grams) } \\
\hline & $\mathrm{Al}_{2} \mathrm{O}_{3}$ & $\mathrm{CaO}$ & $\mathrm{MgO}$ & $\mathrm{SiO}_{2}$ & $\mathrm{Na}_{2} \mathrm{O}$ & $\mathrm{CaF}_{2}$ & $\mathrm{CaO}$ & $\mathrm{Al}_{2} \mathrm{O}_{3}$ & Total & $\begin{array}{c}\text { Calcined } \\
\text { waste }\end{array}$ \\
\hline CICA1 & 20.0 & 65.0 & 0.00 & 0.00 & 15.0 & 0.00 & 27.3 & 8.4 & 42 & 0 \\
\hline CICA2 & 25.0 & 65.0 & 0.00 & 0.00 & 10.0 & 0.00 & 27.3 & 10.5 & 42 & 0 \\
\hline CICA3 & 30.0 & 60.0 & 0.00 & 0.00 & 10.0 & 0.00 & 25.2 & 12.6 & 42 & 0 \\
\hline CICA4 & 25.0 & 60.0 & 0.00 & 0.00 & 15.0 & 0.00 & 25.2 & 10.5 & 42 & 0 \\
\hline CICA5 & 15.0 & 75.0 & 0.00 & 0.00 & 10.0 & 0.00 & 31.5 & 6.3 & 42 & 0 \\
\hline CIRM6 & 15.49 & 50.47 & 18.21 & 4.21 & 11.62 & 0.00 & 27.3 & 8.4 & 83.2 & 39.5 \\
\hline CIRM7 & 19.37 & 50.47 & 18.21 & 4.21 & 7.74 & 0.00 & 27.2 & 10.5 & 83.2 & 39.5 \\
\hline CIRM8 & 23.54 & 47.46 & 17.13 & 3.96 & 7.91 & 0.00 & 25.2 & 12.6 & 80.0 & 36.5 \\
\hline CIRM9 & 19.74 & 47.38 & 17.08 & 3.96 & 11.84 & 0.00 & 25.2 & 10.5 & 80.0 & 36.5 \\
\hline CIRM10 & 11.25 & 56.26 & 20.29 & 4.69 & 7.50 & 0.00 & 31.5 & 6.3 & 89.4 & 45.6 \\
\hline CICAF11 & 30.0 & 60.0 & 0.00 & 0.00 & 0.00 & 10.0 & 25.2 & 12.6 & 42 & 0 \\
\hline CIRMF12 & 23.68 & 47.37 & 17.08 & 3.95 & 0.00 & 7.89 & 25.2 & 12.6 & 80.0 & 36.5 \\
\hline
\end{tabular}

The mixtures from 1 to 5 (ending with $\mathrm{CA}$ ) were formulated in conventional limebased and $\mathrm{Al}_{2} \mathrm{O}_{3}$. The mixtures from 6 to 10 (ending with $\mathrm{RM}$ ) have been made in order to replace the conventional lime for carbonate contained in marble waste. The same $\mathrm{CaO} / \mathrm{Al}_{2} \mathrm{O}_{3}$ ratio was maintained in all of those mixtures. The mixtures 11 and 12 (ending with CAF and RMF) were formulated with fluorspar in order to compare the results obtained with mixtures without $\mathrm{CaF}_{2}$. It was used $30 \mathrm{~kg}$ of slag per ton of cast iron.

The experiments were also carried out to evaluate the lime particle size influence on desulfurization process. Table 2 shows the lime particle size used on desulphurization essays. Table 3 shows the initial composition of the cast iron used in the tests. 
Table 2. Lime particle size used for cast iron desulfurization.

\begin{tabular}{cc} 
Experiment & Particle size \\
\hline $\mathrm{CaO}-1$ & $0.5-1.0 \mathrm{~mm}$ \\
$\mathrm{CaO}-2$ & $100 \mu \mathrm{m}$ \\
$\mathrm{CaO}-3$ & $20 \mu \mathrm{m}$ \\
\hline
\end{tabular}

Table 3. Initial composition of the cast iron.

\begin{tabular}{cccccc}
\hline \multirow{2}{*}{ Mixtures } & \multicolumn{4}{c}{ Chemical composition (wt \%) } & \multirow{2}{*}{ Mass $(\mathrm{kg})$} \\
\cline { 2 - 5 } & $\mathrm{C}$ & $\mathrm{Si}$ & $\mathrm{P}$ & $\mathrm{S}$ & \\
\hline CICA1 & 3.26 & 1.64 & 0.054 & 0.103 & \\
CICA2 & 3.18 & 1.64 & 0.054 & 0.084 & \\
CICA3 & 3.20 & 1.61 & 0.050 & 0.090 & \\
CICA4 & 3.28 & 1.68 & 0.056 & 0.103 & \\
CICA5 & 3.22 & 1.68 & 0.056 & 0.096 & \\
CIRM6 & 3.20 & 1.72 & 0.057 & 0.084 & \multirow{2}{*}{1.4} \\
CIRM7 & 3.16 & 1.72 & 0.053 & 0.084 & \\
CIRM8 & 3.24 & 1.69 & 0.052 & 0.082 & \\
CIRM9 & 3.32 & 1.73 & 0.057 & 0.087 & \\
CIRM10 & 3.37 & 1.7 & 0.064 & 0.091 & \\
CICAF11 & 3.25 & 1.71 & 0.064 & 0.101 & \\
CIRMF12 & 3.28 & 1.73 & 0.059 & 0.091 & \\
\hline
\end{tabular}

\subsection{Experimental apparatus used and experimental procedures}

The experiments were performed in the Metallurgical Technology laboratory of Duisburg-Essen University. Figure 1 shows the experimental apparatus used.

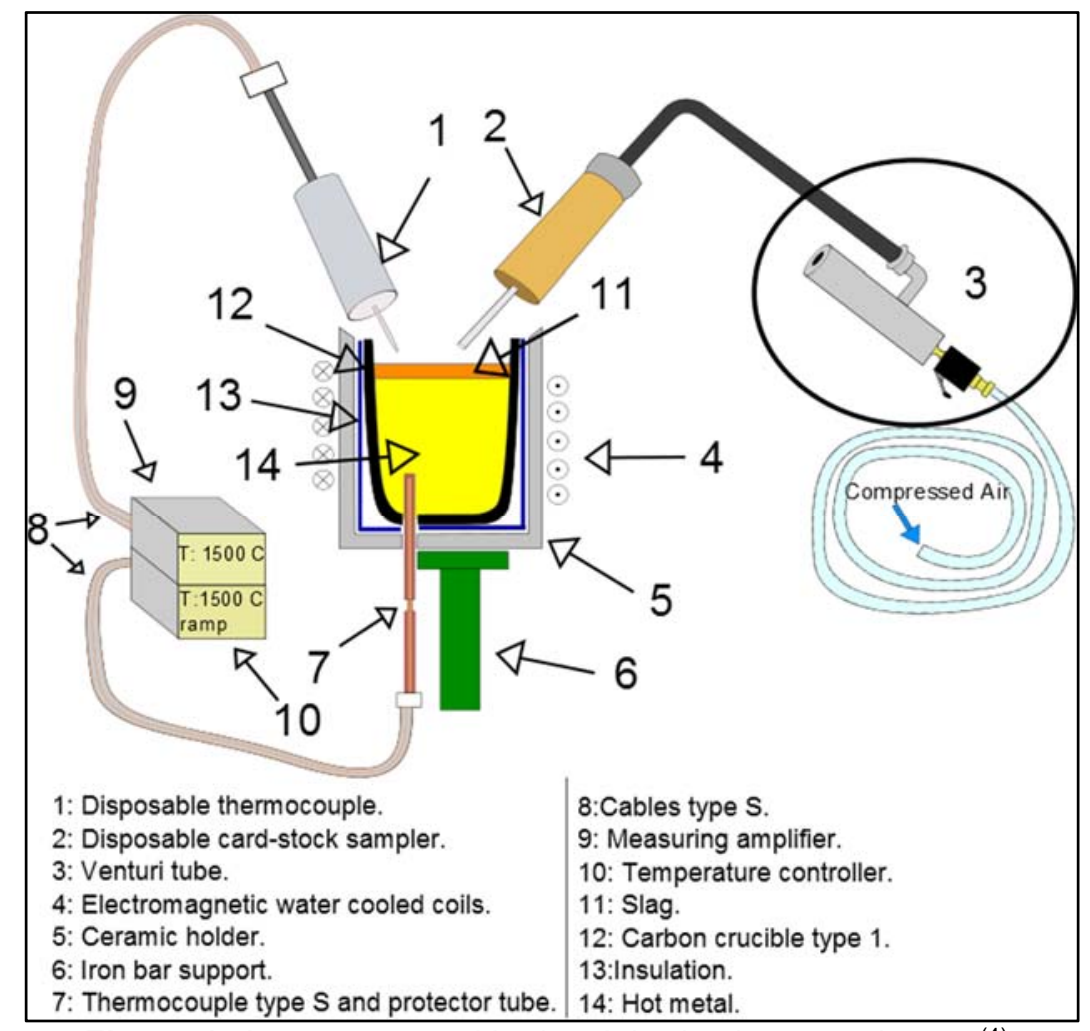

Figure 1. Apparatus used in desulphurization experiments ${ }^{(4)}$. 
A mass of $1.4 \mathrm{~kg}$ of cast iron was placed into a carbon crucible. This crucible was enveloped with a carbon ceramic blanket to avoid heat losses and, then, inserted in an alumina crucible. Agitation was promoted by the induction furnace. After reaches $1550^{\circ} \mathrm{C}$, it was collected a sample to perform the metal chemical analysis. Samples were obtained each 5 minutes. The full experimental time was set up in 45 minutes. The slag was added in 3 times $(0,15$ and 30 minutes). After the end of the experiments, the samples were analyzed for mass optic spectrometry. Thermocalc $₫$ software was used in order to compare the theoretical equilibrium contents and both liquid and solid fractions with the values obtained in experimental tests. The database used in the software was the "SLAG3".

\section{RESULTS AND DISCUSSION}

Figure 2 shows the sulfur variation versus time for: (A) - slags containing conventional lime; (B) - slags containing marble waste. Table 4 shows the equilibrium contents in the cast iron after thermodynamics calculations via Thermo-Calc $®$ and the desulfurization yield $\eta(\%)$.

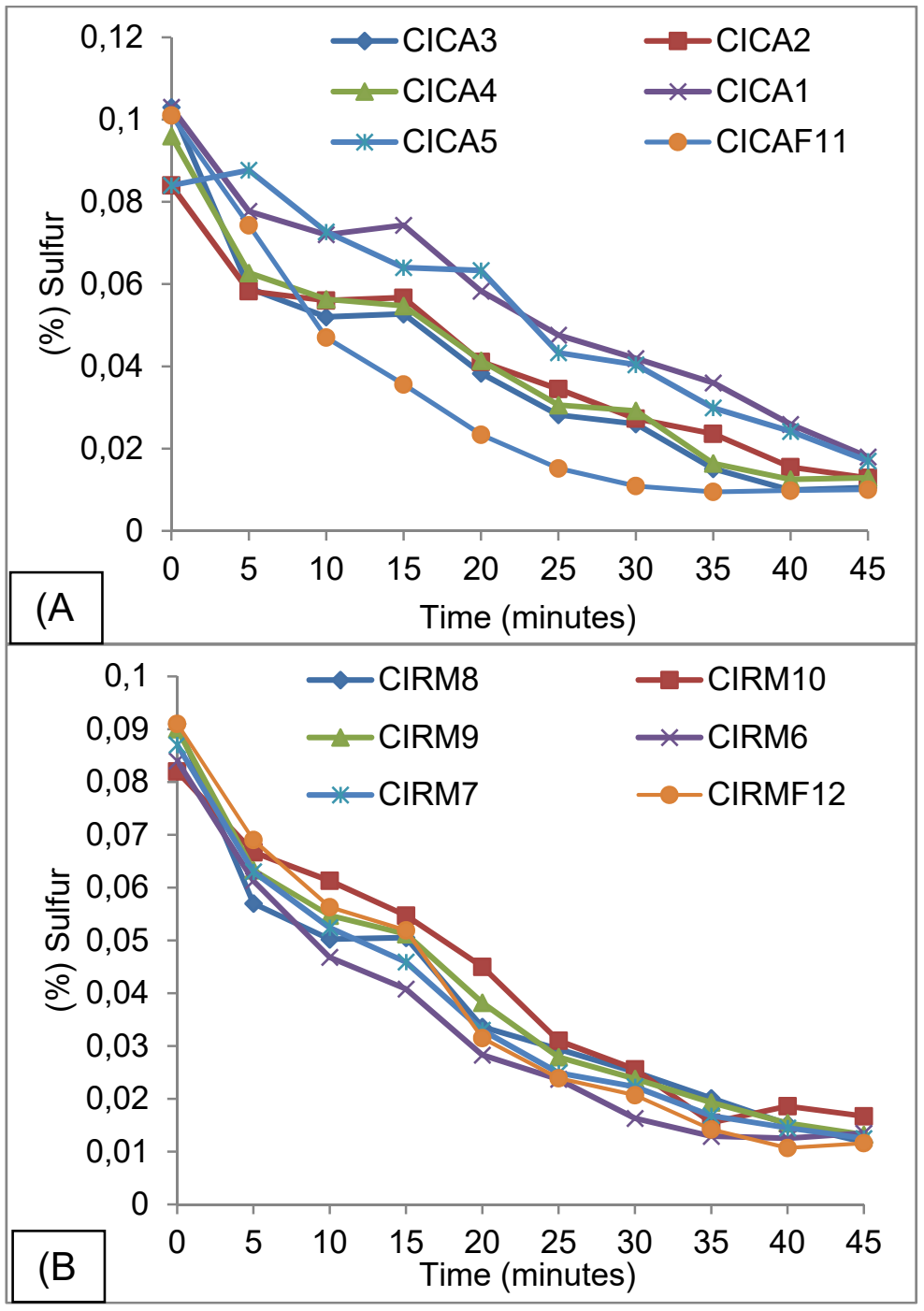

Figure 2. Sulfur variation versus time (A - conventional lime; B - marble waste). 
Table 4. Equilibrium ( $w t \%$ ) obtained for Thermo-Calc $®$ in cast iron and desulfurization yield $(\eta(\%))$.

\begin{tabular}{cccccc}
\hline Mistura & {$\left[\% \mathrm{~S}_{\text {eq. }}\right]$} & {$\left[\% \mathrm{Si}_{\text {eq. }}\right]$} & {$\left[\% \mathrm{C}_{\text {eq. }}\right]$} & {$[\% \mathrm{Mn}]$} & $\eta(\%)$ \\
\hline CICAF11 & $5.17 \mathrm{E}-05$ & 1.61 & 3.19 & 0.53 & 90.10 \\
CICA3 & $2.21 \mathrm{E}-04$ & 1.59 & 3.18 & 0.53 & 89.81 \\
CIRMF12 & $5.75 \mathrm{E}-05$ & 1.62 & 3.19 & 0.55 & 87.25 \\
CIRM8 & $3.95 \mathrm{E}-04$ & 1.56 & 3.18 & 0.53 & 87.03 \\
CICA4 & $1.74 \mathrm{E}-04$ & 1.53 & 3.18 & 0.53 & 86.56 \\
CIRM7 & $1.36 \mathrm{E}-04$ & 1.56 & 3.19 & 0.53 & 85.63 \\
CIRM9 & $3.46 \mathrm{E}-04$ & 1.54 & 3.18 & 0.54 & 85.33 \\
CICA2 & $6.30 \mathrm{E}-05$ & 1.54 & 3.19 & 0.53 & 84.64 \\
CIRM6 & $1.49 \mathrm{E}-04$ & 1.53 & 3.19 & 0.53 & 83.93 \\
CICA1 & $6.41 \mathrm{E}-05$ & 1.51 & 3.19 & 0.53 & 82.52 \\
CICA5 & $6.30 \mathrm{E}-05$ & 1.54 & 3.19 & 0.53 & 79.76 \\
CIRM10 & $6.26 \mathrm{E}-05$ & 1.53 & 3.20 & 0.54 & 79.63 \\
\hline
\end{tabular}

The experiments CIRM6 and CIRM7, which used marble waste were better desulfurizer $(83.93 \%$ and $85.63 \%$, respectively) when compared with experiments using conventional lime CICA1 and CICA2 (desulfurization yield of $82.52 \%$ and $84.64 \%$, respectively). In the experiments CICA3, CICA4 and CICA5, conventional lime showed better results than the experiments with marble waste addition (CIRM8, CIRM9 and CIRM10).

The mixtures with lower equilibrium sulfur values were those with $\mathrm{CaF}_{2}$ in the composition (CICAF11 and CIRMF12). Then, the mixtures contained higher percentages of $\mathrm{CaO}$ in the compositions (CICA5 and CIRM10). The higher thermodynamic potential to desulfurization do not mean higher desulfurization yield, since kinetic factors should be considered $(5,6)$. Table 5 shows both liquid and solid phases contained in the initial mixtures, phases formed in the solid and the equilibrium sulfur content when only the liquid phase is considered in the desulfurization $\left[S_{\text {eq }}\right]$ liq.

Table 5. Equilibrium calculations from initial mixtures of cast iron via Thermo-Calc®

\begin{tabular}{|c|c|c|c|c|c|c|c|}
\hline \multirow[t]{2}{*}{ Mixtures } & \multirow[t]{2}{*}{$\begin{array}{l}\text { Liquid } \\
\text { Phase } \\
\text { (wt \%) }\end{array}$} & \multirow{2}{*}{$\begin{array}{c}\text { Mass of } \\
\text { the Liquid } \\
\text { Phase } \\
\text { (grams) }\end{array}$} & \multirow[t]{2}{*}{$\begin{array}{l}\text { Solid } \\
\text { Phase } \\
\text { (wt \%) }\end{array}$} & \multicolumn{2}{|c|}{$\begin{array}{l}\text { Phases formed } \\
\text { in the Solid } \\
\text { Phase (wt \%) }\end{array}$} & \multirow[t]{2}{*}[S_{\text{eq}}]{$_{\text {liq }}$} & \multirow[t]{2}{*}{$\eta(\%)$} \\
\hline & & & & $\mathrm{CaO}$ & $\mathrm{MgO}$ & & \\
\hline ClCAF11 & 88.02 & 36.97 & 11.98 & 11.97 & 0 & 0.00057 & 90.10 \\
\hline CICA3 & 82.74 & 34.75 & 17.26 & 17.26 & 0 & 0.00149 & 89.81 \\
\hline CIRMF12 & 82.39 & 29.99 & 17.61 & 4.14 & 13.47 & 0.00102 & 87.25 \\
\hline CIRM8 & 73.26 & 26.67 & 26.74 & 13.7 & 13.04 & 0.00354 & 87.03 \\
\hline CICA4 & 75.18 & 31.58 & 24.82 & 24.82 & 0 & 0.00065 & 86.56 \\
\hline CIRM7 & 63.00 & 24.89 & 37.00 & 22.15 & 14.84 & 0.00433 & 85.63 \\
\hline CIRM9 & 67.14 & 24.44 & 32.86 & 19.84 & 13.01 & 0.00484 & 85.33 \\
\hline CICA2 & 70.45 & 29.59 & 29.55 & 29.55 & 0 & 0.00175 & 84.64 \\
\hline CIRM6 & 56.17 & 22.19 & 43.83 & 28.78 & 15.04 & 0.00554 & 83.93 \\
\hline CICA1 & 62.97 & 26.45 & 37.03 & 37.03 & 0 & 0.00344 & 82.52 \\
\hline CICA5 & 46.05 & 19.34 & 53.95 & 53.95 & 0 & 0.00465 & 79.76 \\
\hline CIRM10 & 43.39 & 19.74 & 56.61 & 38.36 & 18.25 & 0.00751 & 79.63 \\
\hline
\end{tabular}

It was noted a linear relationship between the liquid phase and desulfurization yield, as it can be seem in figure 3. The equations obtained were used as parameter to describe the behavior of slags based in $\mathrm{CaO}-\mathrm{Al}_{2} \mathrm{O}_{3}$ and marble waste to desulfurization of cast iron by top slag. 


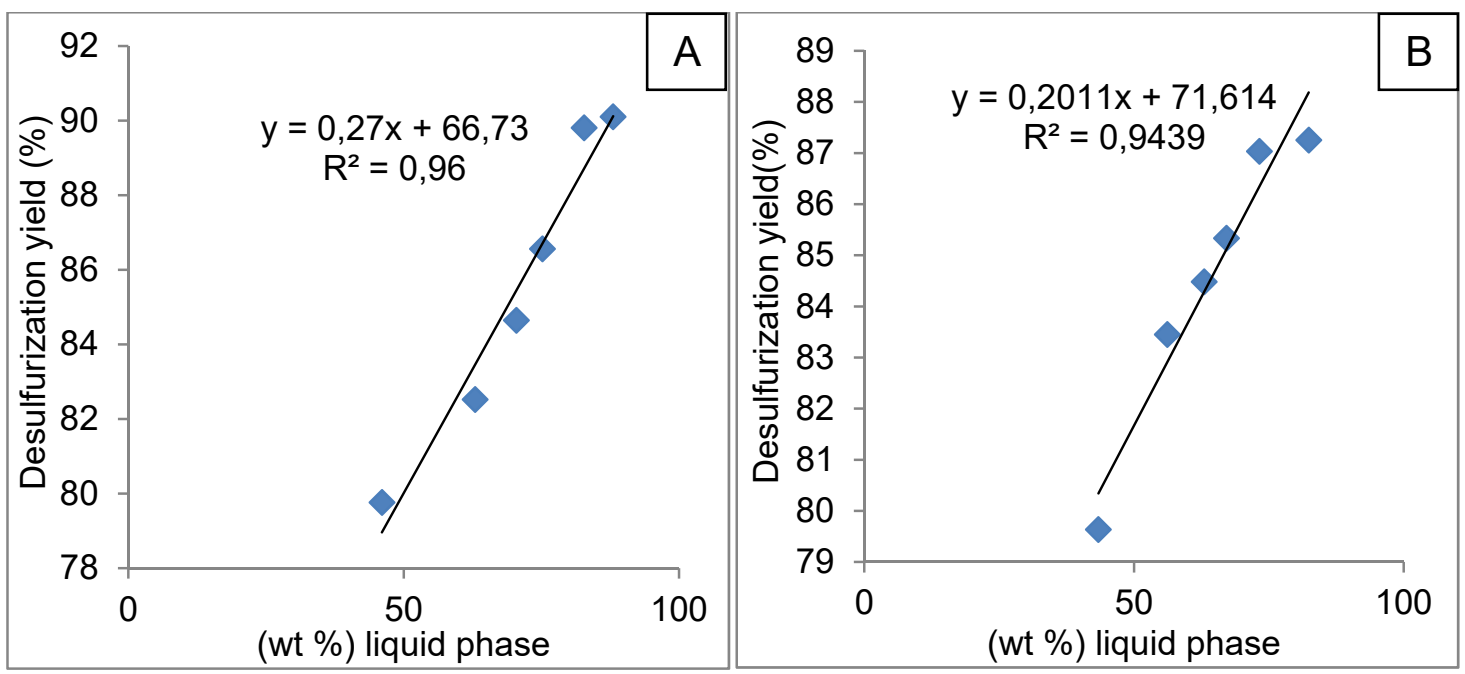

Figure 3. Relationship between liquid phase and desulfurization yield.

The linear correlation coefficient $\left(R^{2}\right)$ was 0.96 to the conventional lime-based slags (Figure $3 \mathrm{~A}$ ) and 0.94 to the mixtures with addition of marble waste (Figure $3 \mathrm{~B}$ ). In this case, increasing the liquid phase, the mass transport of sulfur into the slag and in the interface metal/slag is more effective, favoring the desulfurization ${ }^{(7)}$. Increasing the liquid phase increase the free $\mathrm{CaO}$ content to react. Figure 4 shows the relation between the $\mathrm{CaO}$ content in liquid phase against the desulfurization yield.
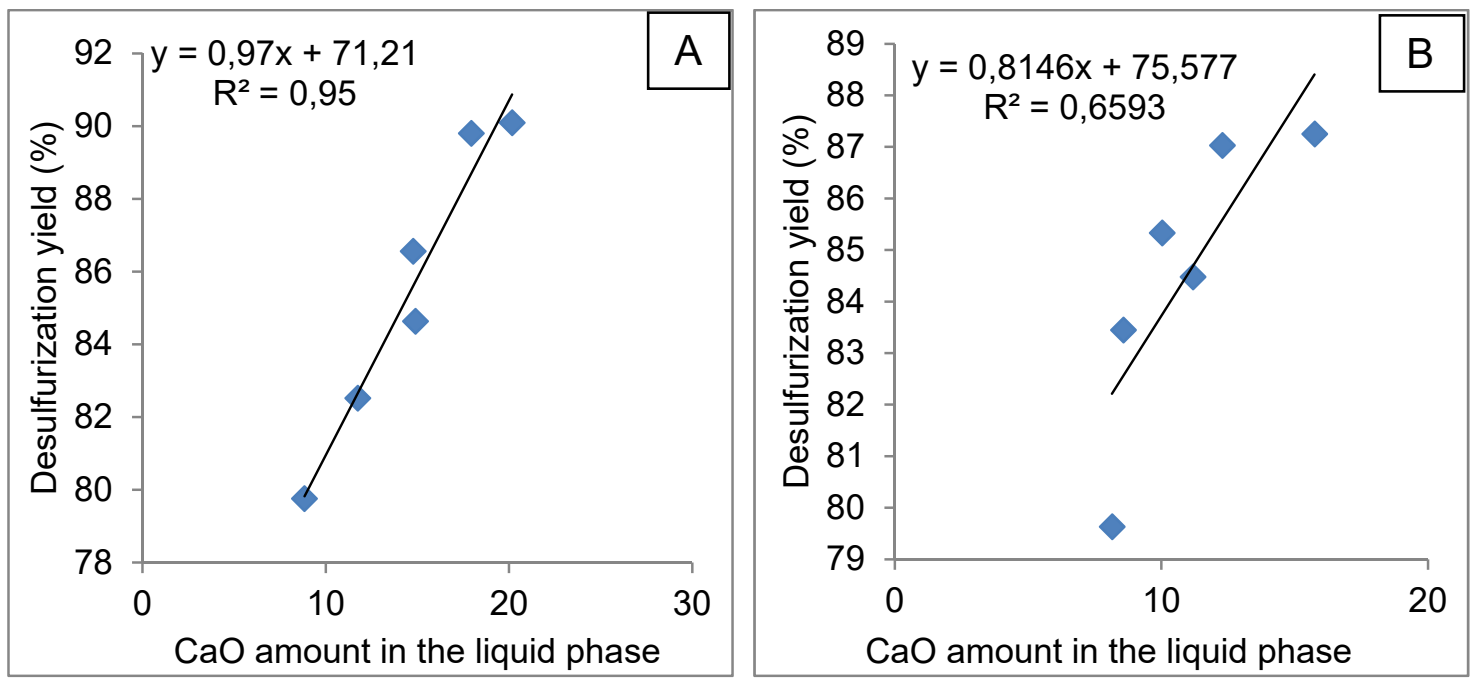

Figure 4. Relation between $\mathrm{CaO}$ amount in the liquid phase and desulfurization yield of the slags based on conventional lime $(A)$ and marble residue $(B)$.

For the mixtures prepared with conventional lime, the results show that the amount of $\mathrm{CaO}$ in the liquid phase has correlation with the desulfurization yield $\left(R^{2}=0.95\right)$. On the other hand, for the mixtures carried out with marble waste, it wasn't observed the same linear behavior. Thereby, it was assumed that concentration of solid $\mathrm{MgO}$ in the marble waste may interfere negatively in the desulfurization. From Table 5, it can be noted that increasing the solid $\mathrm{MgO}$ decreasing both liquid phase and efficiency. Even the carbonates decomposition has favored the desulfurization, the solid $\mathrm{MgO}$ decreases the process.

In order to compare the substitution of fluorspar for $\mathrm{Al}_{2} \mathrm{O}_{3}$, slags containing marble waste and conventional lime with the same $\mathrm{CaO}$ mass were studied. Comparing the desulfurization yield obtained by slags containing conventional lime (CICAF11 and 
CICA3), it was noted values of $90.1 \%$ and $89.81 \%$, respectively. In this way, the substitution of fluorspar for $\mathrm{Al}_{2} \mathrm{O}_{3}$ might be viable. The slags with marble waste (CIRMF12 and CIRM8) showed desulfurization yield of $87.0 \%$. This result places the marble waste as an alternative substitute to the conventional lime, since the efficiency is close to that efficiency obtained for slags with conventional lime.

Figure 5 shows the influence of particle size in the process.

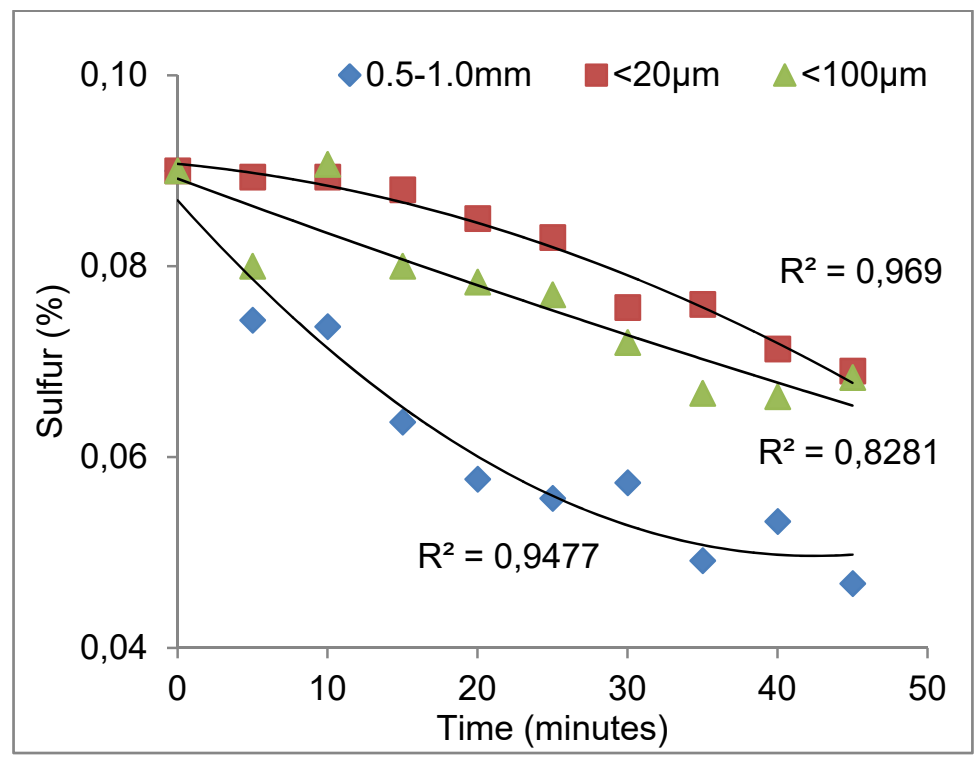

Figure 5. Amount of sulfur versus time.

It can be noted in figure 5 that increasing the $\mathrm{CaO}$ particle size favors the desulfurization process. It may be contradictory, since decreasing the particle size increase the surface area. However, it was observed that slags with particle size of $20 \mu \mathrm{m}$ and $100 \mu \mathrm{m}$ were sintered after addition on the metal. This result was similar to that found for McFEATERS and FRUEHAN(8). Figure 6 shows agglomeration phenomenon observed during the experiments.

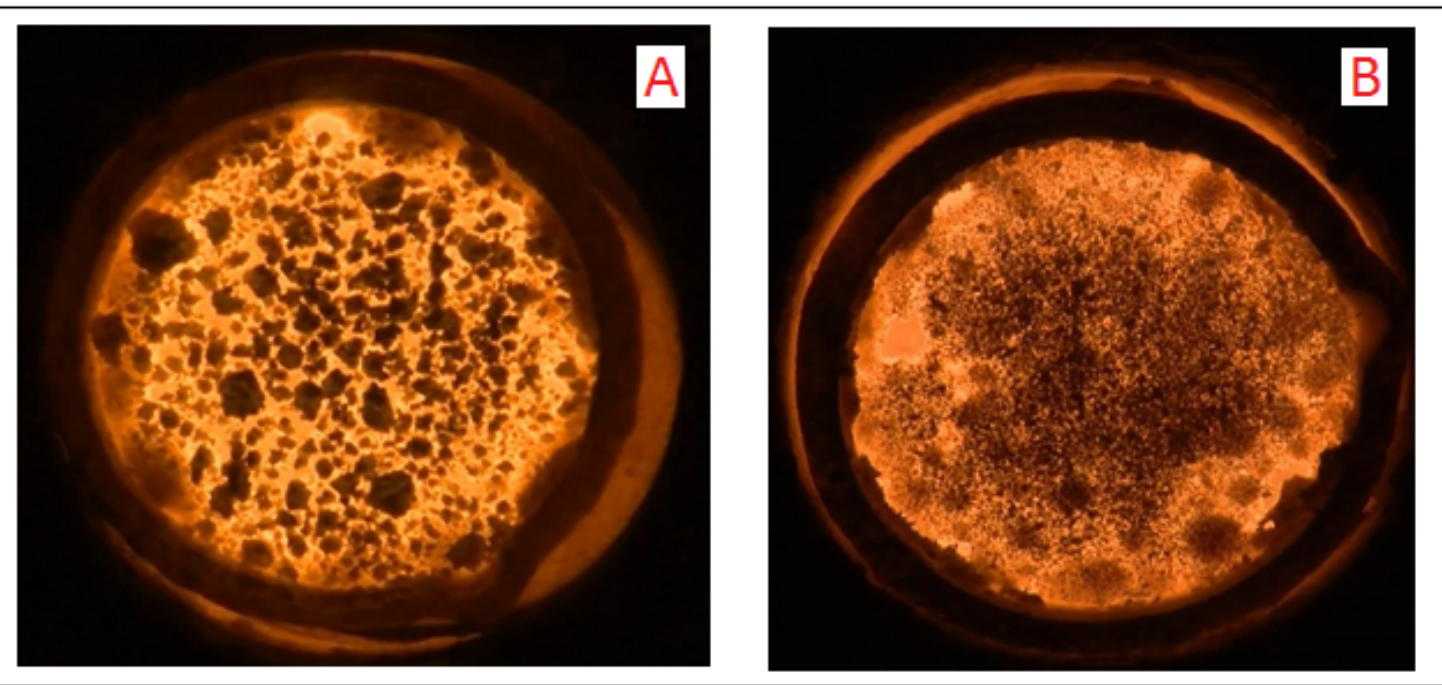

Figure 6. Picture taken at 5 minutes of analysis with lime: $(A)<100$ presenting particle agglomeration; (B) between $0.5-1.0 \mathrm{~mm}$, showing that the process of agglomeration doesn't occur. 


\section{CONCLUSION}

The mixtures with addition of marble waste that obtained the best desulfurization yield were: CIRMF15 e CIRM8 (87.25\% and $87.03 \%)$. The best results obtained from conventional lime were: CICAF11 and CICA3 (90.10\% and $89.81 \%)$. The computational thermodynamic analysis showed lower sulfur equilibrium to the mixtures CICAF11, CIRMF12, CICA5 and CIRM10. The MgO concentration in slags containing marble waste interfered negatively in the desulfurization yield, decreasing both liquid phase fraction and efficiency. Increasing the liquid phase favored both sulfur mass transport into the slag and in the metal/slag interface, raising the mixtures desulfurization yield. Increasing the $\mathrm{CaO}$ particle diameter improved the desulfurization process. Particle with diameter in range of 20 to $100 \mu \mathrm{m}$ were sintered after addition on the metal, harming the desulfurization. The substitution of fluorspar for $\mathrm{CaO}-\mathrm{Al} 2 \mathrm{O} 3$ system slags is a viable alternative as well the substitution of conventional lime for marble waste.

\section{REFERENCES}

1 Various, "Magnesium Metal: Global Industry Markets \& Outlook," ROSKILL, London, 2013. Disponível http://www.roskill.com/magnesium-metal.

2 Dyudkin, D.A., Kisilenko, V.V., Onishchuk, V.P. et al., User of Powder Wire for Ladle Desulfurization of Cast Iron, Chern. Metallurg., $n^{\circ}$ 1, p. 41-49, 2003.

3 Zborshchik, A.M. and Tsuprun, A. Yu., Rational Technologies for Ladle Desulfurization of Cast Iron in the Conditions of Metallurgical Plants in Ukraine, Journal: Steel in Translation, $\mathrm{n}^{\circ}$. 8, p. 28-30. 2002.

4 Bretz, G.: Desulfurization of cast iron with CaO-based agents on a laboratory scale, Master Thesis, University Duisburg-Essen, 2015.

5 NIEDRINGHAUS, J. C.; FRUEHAN, R. J. Reaction mechanism for the CaO-Al and $\mathrm{CaO}-\mathrm{CaF}_{2}$ desulfurization of carbon-saturated iron. Metallurgical Transactions $B$. v. 19B, p. 261-268, 1988.

6 GRILLO, F. F.; SAMPAIO, R. A.; VIANA, J. F.; ESPINOSA, D. C. R.; OLIVEIRA, J. R. Analysis of pig iron desulfurization with mixtures from the CaO-Fluorspar and $\mathrm{CaO}$ Sodalite system with the use of computational thermodynamics. Revista Escola de Minas, v. 66, p. 461-465, 2013.

7 FRUEHAN, R. J. Desulfurization of liquid steel containing aluminum or silicon with lime. Metalurgical transactions B, v. 9, p. 287-292, 1978.

8 McFEATERS, L. B.; FRUEHAN, R.J. Desulfurization of Bath Smelter Metal. Metallurgical Transactions B, v. 24B, p. 441-447, 1993. 